\title{
EARLY 2015 PERFORMANCE IN BALTIC SEA PORTS: FORECASTS OF ESTONIAN PERFORMANCE FOR ENTIRE YEAR
}

\author{
Olli-Pekka Hilmola ${ }^{1}$, Andres Tolli ${ }^{2}$ \\ ${ }^{1}$ Lappeenranta University of Technology \\ Kouvola Unit, Prikaatintie 9, FIN-45100 Kouvola, Finland \\ Fax: +358 5344 4009, E-mail: olli-pekka.hilmola@lut.fi \\ ${ }^{2}$ Tallinn University of Technology, Estonian Maritime Academy \\ Kopli 101, 11712 Tallinn \\ Phone: +372 5071 899, e-mail: andres.tolli@ttu.ee
}

\begin{abstract}
Many changes have appeared in year 2015. In Europe economic malaise has continued since debt crisis started in year 2010, and although its effects on Northern Europe have started to diminish, new economic dark clouds have appeared through sanctions set by both European Union and Russia to each other during year 2014. Together with these, shipping sector has been under pressure due to strict sulphur regulation implemented from early 2015 onwards in the entire Baltic Sea Region. Due to these factors, sea ports at Baltic Sea have been under pressure during the first months of 2015, this particularly concerning container handling. Based on our regression model forecast, Estonia and Port of Tallinn shall have clearly declining container handling year ahead. However, overall handling at sea port is not so easy to forecast.
\end{abstract}

Keywords: Baltic Sea, crisis, sea ports, handling, TEU

\section{Introduction}

Development of economies after global financial credit crunch (years 2008-2009) has been rather difficult to all North European countries (e.g. Baltic States, see (Hilmola, 2013)). This global economic downturn was followed by debt crunch of Southern Europe, which has had its effects on local economies and logistics sector development since 2010. On a top of these, transportation, and particularly sea transportation sector, have been under tremendous environmental regulation process in Baltic Sea Region. In year 2010 as first in the world sulphur content of diesel at Baltic Sea was lowered to $1.0 \%$, which was continued with stiff decline to $0.1 \%$ level in year 2015 (Notteboom, 2011; IMO, 2015; Hilmola, 2015). This has lead to higher fuel costs for ships and a somewhat higher freight rates. Under horizon is also nitrogen ban on ships (Corbett et al., 1999), which has now been postponed for some years (Helcom, 2014). Together with this $\mathrm{CO}_{2}$ emissions of shipping are closely followed and some actions or payment systems are to be expected to be implemented in the future (Ellerman et al., 2010; Stead, 2006).

On positive side, Baltic Sea Region has been surrounded by two powerful economies, those of Germany and Russia. In addition, Poland has received increasing amount of greenfield investments on manufacturing sector (UNCTAD, 2014). However, these positive developments have been constrained since year 2014 as political dispute between Russia and European Union developed. Together with EU, sanctions have been supported by USA. Sanctions and trade limitations have been implemented in both directions - especially in Baltic Sea Region and analyzed countries of this research have been hit hard by Russian ban to import of food and food products from EU. Sanctions have resulted on declining trade and this inevitably has its effects on logistics sector, and sea ports. It should be reminded that sea ports are not small issue for analyzed local economies of this research work. Situation even without sanctions is not easy for transportation chains - numerous basic problems remain between EU countries and CIS, and entire transportation chain is not even wanted to be managed by single body (Bazaras et al., 2015). However, in long-term eastern Baltic Sea countries have completed significant changes and investments (e.g. early situation, see (Buchhofer, 1995; Ország-Land, 2000), and act now as major connecting area between east and west (Hilmola, 2011).

They offer a reasonably high amount of work for local people, and typically salary level is higher than in other sectors. For example in Estonian logistics sector involved directly 33000 employees and indirectly 49000 employees (accounts $7.84 \%$ of all employees). In Estonia the total estimated number of employees in 2014 was 625000 (Statistics Estonia, 2015). The transit sector employs 8000 employees (Tender and Kalmer, 2013). 
In addition, maintenance and investments on sea port handling capacity and supporting infrastructure is important issue from economic side. Together with these, material handling at ports supports e.g. hinterland transportation as freight flows at railways are key for railway sector infrastructure maintenance funds (Thompson, 2008). Passenger transport is enabled in number of countries too, due to sea ports and their freight flows (in such countries like Russia, Estonia, Latvia and Lithuania, also in parts in Poland; see e.g. from case of Russia annual results of (RZD, 2012; Baltic Course, 2015)). Crisis in 20082009 showed that logistics sector has far wider implications on local economies than could be imagined in the first place (Hilmola, 2013; Sakiene, 2011).

Motivation of our research work is the greatly changing business environment at sea transports during year 2015. Earlier nearly all analyzed sea ports were on constant growth track, and actually 2008-2009 economic crisis was only contemporary phenomenon, which was surpassed in few years. This not only concerns Russia, but also the Polish sea port of this study and all Baltic States sea ports. Only in Finland volume growth has been extremely sluggish e.g. in containers and real recovery from the 2008-2009 crisis still waits to come. Therefore, this new environment is worth to analyze in light of changes of early 2015, and available early year data of sea port handling. Research questions to be answered in this study are following ones: (1) 'How have demand developed overall and in containers being handled?', and (2) 'Could early months be used as proxy for entire year performance?'

This research is structured as follows: In Section 2 is being analyzed sea port handling performance of most important sea ports of Baltic Sea concerning Poland, Lithuania, Latvia, Estonia, Russia and Finland. For all of these countries sea ports hold high importance due to the distance to Central Europe. This analysis is followed by regression forecast models developed in Section 3 concerning port of Tallinn and its overall sea port handling and container throughput. Final Section 4 concludes our work, where we also propose further research avenues.

\section{Analysis of Sea Port Performance in January-February 2015}

Overall Baltic Sea ports have done well as compared, what is the macro economic environment (resulting on sluggish demand or declining one) and the new environmental demands set by sulphur directive (cost increase). As Table 1 illustrates, growth has continued in Gdansk, Klaipeda and Riga. Also some Russian sea ports have done well such as Ust-Luga and Primorsk. However, it should be noted that latter one was having declining volumes in year 2014, and therefore it is relatively easy for it to show growth in year 2015. In Finnish and Estonian sea ports situation is inconsistent. Port of Helsinki shows moderate growth as port of HaminaKotka in turn records similar decline. Port of Tallinn is in significant decline; situation is the same in the port of Ventspils.

As many sea ports in Table 1 are handling a lot of oil and raw materials, was analysis completed regarding to sub-cargo groups. It was interesting to note that in general, growth is supported by handling of raw materials. For example, in Ust-Luga growth could be explained with oil and oil products as well as coal related raw materials handling. In Primorsk single handled cargo group is oil, which is in somewhat growing track. In Kaliningrad wheat and sugar handling together with roro cargo cause it. Riga is still growing with dry bulk, namely coal. Fertilizers and liquids have been the strength of Klaipeda. Fertilizers cargo flow also supported by Belarus. The state is the world biggest supplier of potassium mineral fertilizers. Belarus also is using Port of Klaipeda container terminals as gateway for import of the consumer goods. By estimation totally up to 125000 containers in a year are transported from Port of Klaipeda to Belarus by truck. Situation is similar with Gdansk, where dry bulk and liquids have supported volumes. Only in Helsinki container and roro cargo handling, not that significantly raw materials, enable its moderate growth.

Table 1. Cargo handled in different Baltic Sea Ports during January-February 2015 ('000 tons). Sources (data): (Baltic Sea Ports, 2015)

\begin{tabular}{l|l|r|r|}
\multicolumn{1}{l}{ Country } & \multicolumn{1}{l}{ Sea Port } & \multicolumn{1}{l}{ Tons } \\
\hline \hline Finland & Helsinki & 1764.0 & $5.1 \%$ \\
\hline & HaminaKotka & 2230.1 & $-4.0 \%$ \\
\hline Russia & Ust-Luga & 13454.4 & $23.8 \%$ \\
\hline St. Petersburg & City Sea Port & 8099.6 & $-7.6 \%$ \\
\hline & Primorsk & 9890.1 & $7.6 \%$ \\
\cline { 2 - 4 } & Kaliningrad & 2191.7 & $4.1 \%$ \\
\hline Estonia & Tallinn & 4349.1 & $-19.1 \%$ \\
\hline Latvia & Riga & 6834.1 & $4.7 \%$ \\
\hline & Ventspils & 4827.0 & $-18.3 \%$ \\
\hline Lithuania & Klaipeda & 5959.5 & $9.0 \%$ \\
\hline Poland & Gdansk & 5225.9 & $4.5 \%$ \\
\hline
\end{tabular}


In Table 1 sea ports showing higher volume drops are Tallinn and Ventspils. In both of these, cause of decline is mostly explained with raw materials, and that of liquids (oil and oil products; biggest volume group). Also in Tallinn other product groups have declined such as container handling. In Ventspils all reported cargo groups are in somewhat declining path. HaminaKotka shows minor decline, which is mostly caused due to the dynamics of forest industry. Imports of wood to HaminaKotka declined as did the exports of some forest industry end products together with unitized export cargo.

Table 2. Containers handled in different Baltic Sea Ports during January-February 2015 (in TEUs). Sources (data): (Baltic Sea Ports, 2015)

\begin{tabular}{l|l|r|r|}
\multicolumn{1}{l}{ Country } & \multicolumn{1}{l}{ Sea Port } & \multicolumn{1}{l}{ TEUs } & \multicolumn{1}{l}{ Change } \\
\hline \hline Finland & Helsinki & 64298 & $3.2 \%$ \\
\hline & HaminaKotka & 94795 & $-8.4 \%$ \\
\hline Russia & Ust-Luga & 15098 & $-11.8 \%$ \\
\hline St. Petersburg & City Sea Port & 273293 & $-28.8 \%$ \\
\hline & Primorsk & N/A & \\
\cline { 2 - 4 } & Kaliningrad & 25299 & $-53.2 \%$ \\
\hline Estonia & Tallinn & 34462 & $-13.9 \%$ \\
\hline Latvia & Riga & 63167 & $3.0 \%$ \\
\hline & Ventspils & N/A & \\
\hline Lithuania & Klaipeda & 65620 & $-7.3 \%$ \\
\hline Poland & Gdansk & 169509 & $-17.2 \%$ \\
\hline
\end{tabular}

What is interesting under the handling volume surface, is the consistent and significant container handling decline in nearly all analyzed sea ports (except Helsinki and Riga). This is illustrated in Table 2. Typically container cargo does not play importance in overall handling as in tons it can not match volumes of e.g. oil and coal (if sea port handles these too). All Russian sea ports show very significant declines, where it is most alarming the development of city sea port of St. Petersburg; in relative terms drop has been $28.8 \%$, but volume wise it is 110,763 TEU containers. Elsewhere declines are also significant in relative terms, but in volume, only Kaliningrad (28,746 TEU handling decline) and Gdansk (35,249 TEU drop) are showing tens of thousands of handling volume decline. In HaminaKotka, Ust-Luga and Tallinn declines are some thousands of containers, but not higher than nine thousand containers.

In the future, the Baltic Sea container transport market depends to a greater extent on Russia's economic situation and its fluctuations. By today, also container penetration in Russia remains fundamentally low. In Russia production level of consumer goods for retail customers is also low. In practice, ports of all the other countries are competing for Russia-directed transit container flows, for prospective growths are the highest there. It is important to note a positive fact that the majority of Russia's total container flow is transported through the Baltic Sea. More than $80 \%$ of leading container terminal operator in Russia, Global Ports, and its container handling capacity is serving Baltic Sea (Global Ports, 2015).

In overall, it could be said that sea port handling situation in tons is not that extremely bad in Baltic Sea ports, but there are exceptions, and situation is not consistent in group of analyzed sea ports. Volumes are supported by raw materials (liquid and dry bulk), and ports mastering these product groups, are strong also in overall. What is interesting in geographical terms, is the fact that all declining handling volume (tons) ports are located at the level of Ventspils or above. From this it could be at least speculated that environmental demands of sulphur regulation have in parts hurt these longer distance sea ports (to Central Europe, main markets and sea ports), where cargo is needs to proceed longer distance Baltic Sea route and this completed with expensive sulphur free oil. General world trade situation is reflected in port handling of containers, where huge declines have been recorded. These declines could also be explained with sulphur regulation as increasing sea freights prevent or constrain somewhat trade volume of import and export. Under the surface situation is not good, and if situation remains such, it means major problems for economies of the region (as container handling is so tightly tied to economic growth in the Baltic Sea region and in the world).

\section{Using Two First Months to Forecast Entire Year 2015 Performance in the Port of Tallinn}

It could be argued that analyzing entire year and ongoing change at Baltic Sea is invalid with such short amount of data, only two months. We tried this with one port data, concerning Tallinn. Overall availability was from period of 1999-2014, where both total tons handled (Figure 1) and total TEU container amount (Figure 2) were analyzed. This period is sufficient to cover numerous economic crises and 
disturbances as amount of data points are 16. Only potential conflict in here is with TEU container handling amounts, which have been low in early 2000 in Tallinn. Measured in tons, Port of Tallinn has been significant during the entire observation period.

As Figure 1 illustrates, for total tons handled in a year, two first months are not good proxy. However, it is not poor either. Situation is satisfactory as $\mathrm{R}^{2}$ value of simple linear regression model is $46.16 \%$. This means that two first months explain this percentage amount from entire year of port handling. We also did run detailed regression analysis for this relationship, and found that both co-efficient and fixed term in the regression model were statistically significant. Model is having considerable downside in the forecast variation, as standard error is 3590.16 thousand tons. Based on this model forecast for Tallinn concerning year 2015 handling at sea port is just below 30 mill. tons. However, this is under uncertainty due to standard error, and could be easily 3-7 mill. tons wrong (both directions, up or down). Therefore, it is difficult to say whether handling amounts will decline in year 2015. Actually current forecast gives even slight growth as compared to year 2014. This is all because forecast precision is so low and standard error in turn high.

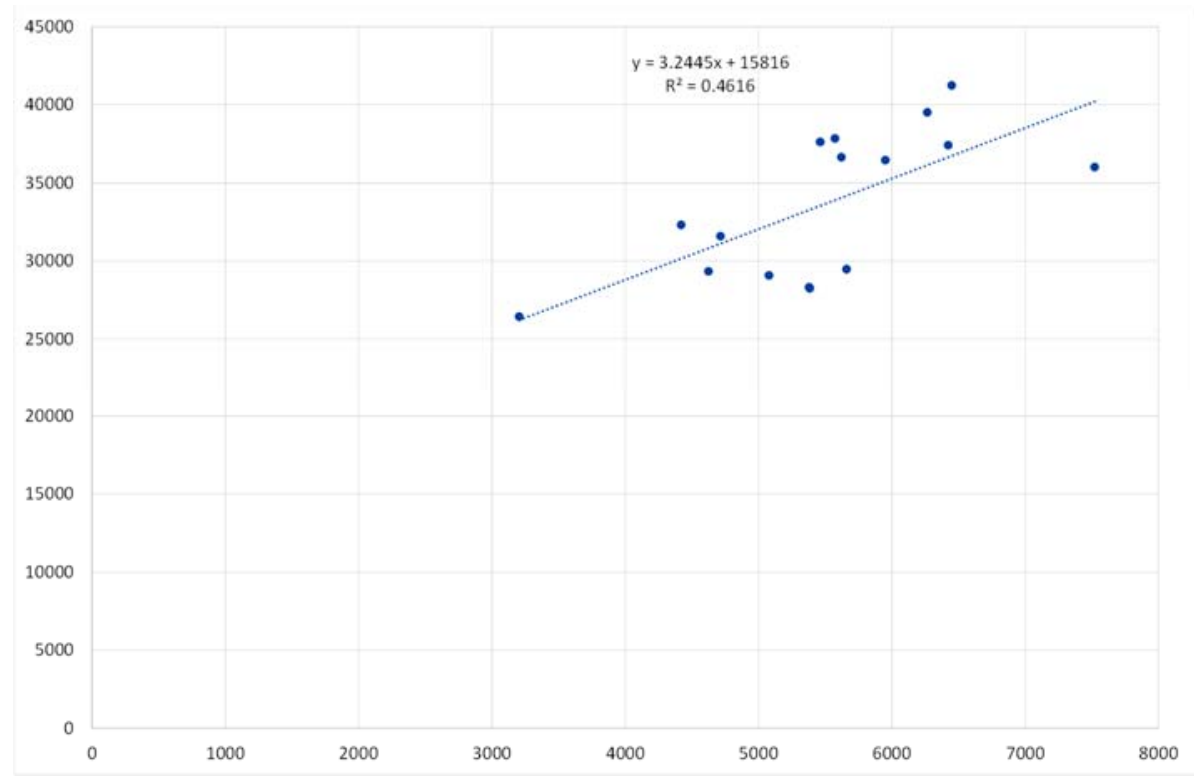

Figure 1. Scatter gram of forecasting entire year of handling ('000 tons, $y$-axis) with two first months of handling ('000 tons, $\mathrm{x}$-axis) in port of Tallinn, Estonia during time period of 1999-2013. Source (data): Port of Tallinn (2015)

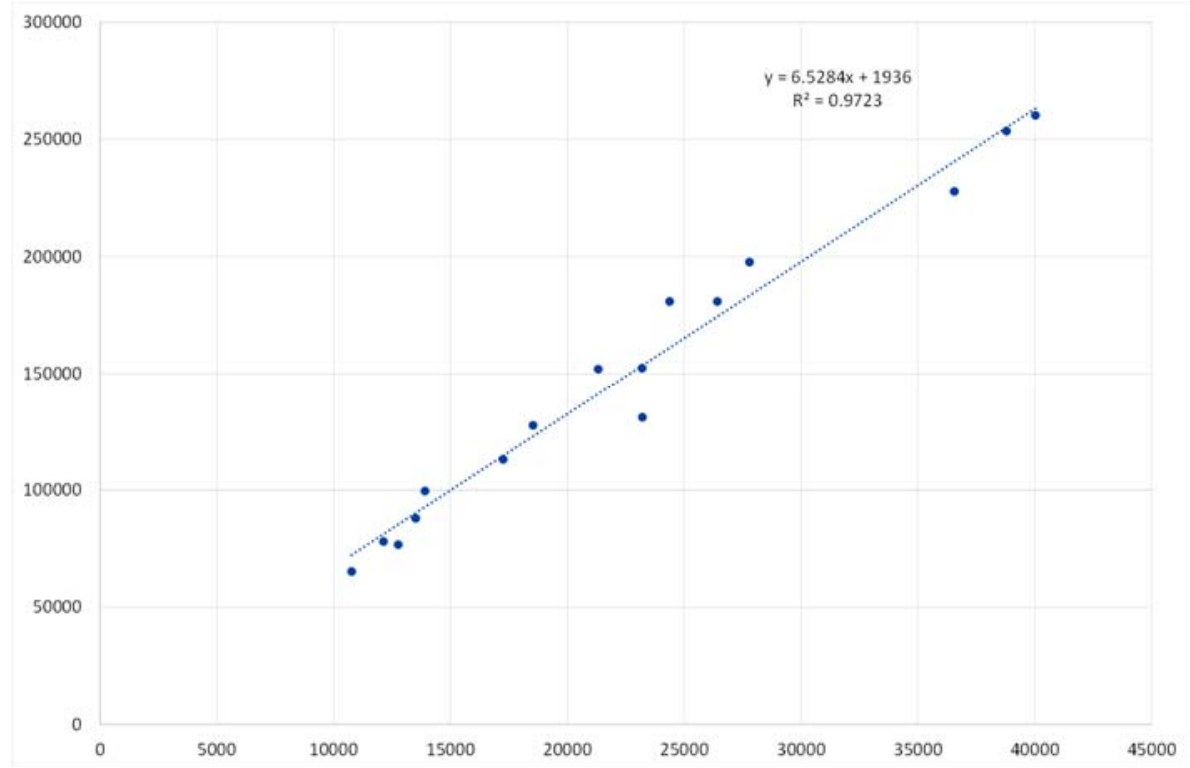

Figure 2. Scatter gram of forecasting entire year of container handling (TEUs, y-axis) with two first months of handling (TEUs, x-axis) in port of Tallinn, Estonia during time period of 1999-2013. Source (data): Port of Tallinn (2015) 
For containers scatter gram and following regression line is producing much better forecast (Figure 2). First two months seem to produce rather consistent view from the entire year and as could be noted, variation among regression line is rather low. If $\mathrm{R}^{2}$ value is analyzed, we may note that proposed regression model forecasts $97.23 \%$ from annual container handling volume. This value is extremely high. However, as we analyzed regression model through statistical analysis, we found that fixed term in Figure 2 linear model was not statistically significant. Co-efficient of Figure 2 was of course statistically significant with extremely high level. This means that regression line should be without fixed term (in Figure 2 this fixed term is 1936). As fixed term was abandoned and regression line was forced to start from zero, then regression model co-efficient was 6.602 and it was able alone to forecast $99.6 \%$ from annual volume with two first months. Standard error of this model is 10508.84 TEU containers (per year). Based on this regression model we could with confidence forecast that year 2015 will be year of decline for Port of Tallinn in container handling. Regression model will forecast actual amount to be 227,519.3 TEUs. This is $12.6 \%$ lower than in year 2014. Even if standard error is taken three times and added to this average handling amount of forecast for year 2015, it could be concluded that year will have lower performance than earlier one. Change does not seem to be extremely significant, but it is first year of decline since year 2009. This year 2014 decline seems to be in the magnitude half from this big drop experienced during global credit crunch.

\section{Conclusions}

Logistics flows and sea ports are important for analyzed countries, not only to support local and regional economies, but also due to their direct effects on employment, income and profits. Especially in all Baltic States logistics sector is huge and important employer. Therefore, its development receives attention and especially negative changes influence local economies in major scale. One example is hinterland transports, which is typically accomplished by railway in case of raw materials. Freight at rails pays one of the highest railway access fees in Europe in all Baltic States, and enables the maintenance of rail network as well as passenger traffic. If freight volumes decline by 10-20\% in one year, it means significant budget problems for railway sector. Similar kind of effect does not only concern Baltic States, but is also concern in Russia. Freight and key industrial product groups have become extremely critical for the countries in concern.

Sea ports have done relatively well (as compared to macro economic environment) during early months of year 2015. This with some exceptions such as Tallinn and Ventspils. Tons handled in the studied sea ports depends greatly on raw material handling, and mostly on oil, oil products, coal and fertilizers. Even if these markets have experienced price declines (end products) lately, it has not affected demand. It seems that demand for these products has sustained rather well in the region (these critical raw materials typically end in European Union member countries). However, as a word of caution remains very low performance on container handling. This is merely connected to local warehousing and value adding logistics sectors, which will bear these effects in their operations. If container handling is about to decline $10-30 \%$ in year 2015, it means another really difficult year for logistics sector companies.

Second part of our empirical analysis concerns the effect of two first months on entire year performance of sea port. In the regression models was used data available from Port of Tallinn. Our analysis showed that two first months have role in both overall tons and containers handled. However, another question remains, whether these models are useful ones. Developed total handling model was having such high standard error in it that forecast for year 2015 overall handling was not accurate enough. Volumes could even increase in this year, as based on the model, even if first two months have been difficult ones. However, container handling model was much higher in accuracy and argued that container volumes in Tallinn will drop in year 2015. This decline will be significant, but not as big as it was in year 2009 .

As a further research, we would be interested to develop models for all sea ports using early information of particular year. In this research work, we used first two months, but observation period could be extended to three and four early months too. This extension could increase the accuracy of forecast. Interest should not only be overall handling in tons or sea containers, but also other cargo groups should be taken into consideration. In e.g. all Baltic States sea ports one raw material group is critical over the other, in Tallinn it is oil and oil products, in Riga it is coal and in Lithuania it is fertilizers. It is not only the interest of sea port to develop these models, but incorporated parties should involve local government and railway sector too. 


\section{References}

1. Hilmola, Olli-Pekka (2013). From Bubble to Sustainable Economy in Baltic States. Journal of Transport and Telecommunication, 14:3, pp. 237-249.

2. Notteboom, T. (2011). The impact of low sulphur fuel requirements in shipping on the competitiveness of roro shipping in Northern Europe. WMU Journal of Maritime Affairs, 10:1, pp. 63-95.

3. IMO (2015). Sulphur oxides (SOx) - Regulation 14. Available at URL: http://www.imo.org/OurWork/Environment/PollutionPrevention/AirPollution/Pages/Sulphuroxides-\%28SOx\%29-\%E2\%80\%93-Regulation-14.aspx Retrieved: April.2015

4. Hilmola, Olli-Pekka (2015). Shipping sulphur regulation, freight transportation prices and diesel markets in the Baltic Sea Region. International Journal of Energy Sector Management, 9:1, pp. 120-132.

5. Helcom (2014). Imo decision on nitrogen emissions from ships provides a clearer framework for the Baltic. Available at URL: http://helcom.fi/imo-decision-on-nitrogen-emissions-from-ships-providesa-clearer-framework-for-the-baltic Retrieved: April.2015.

6. Ellerman, A. D., F. J. Convery, C. De Perthuis, E. Alberola, B. K. Buchner, A. Delbosc, C. Hight, J. H. Keppler and F. C. Matthes (2010). Pricing Carbon: The European Union Emissions Trading Scheme. Cambridge University Press, Cambridge, UK.

7. Stead, Dominic (2006). Mid-term review of the European Commission's 2001 Transport White Paper. European Journal of Transport and Infrastructure Research, 6:2, pp. 365-370.

8. UNCTAD (2014). World Investment Report 2014. United Nations Conference on Trade and Development. New York and Geneva.

9. Bazaras, D., I. Yatskiv, A. Maciulus and R. Palsaitis (2015). Analysis of common governance transport system development possibilities in the East-West transport corridor. Journal of Transport and Telecommunication, 16:1, pp. 31-39.

10. Buchhofer, E. (1995). Transport infrastructure in the Baltic States during the transformation to market economies. Journal of Transport Geography, 3:1, pp. 69-75.

11. Ország-Land, Thomas (2000). Ports in transition: Baltic Europe prepares for a transshipment boom. European Business Review, 12:4.

12. Hilmola, Olli-Pekka (2011). Rail Baltica Influence Area: State of Operating Environment. Lappeenranta University of Technology, Department of Industrial Management. Research Report 236. Lappeenranta, Finland.

13. Statistics Estonia (2015). Employment. Tallinn, Estonia. Available at URL: http://www.stat.ee Retrieved: February.2015.

14. Tender, Teet \& Katrin Kalmer (2013). The extent of the impact of the logistics sector in the Estonian economy (in Estonian, free translation to English). Research. PricewaterhouseCoopers

15. Thompson, Loius S. (2008). Railway Access Charges in the EU: Current Status and Developments Since 2004. OECD / International Transport Forum.

16. RZD (2012). Annual Report of RZD. Moscow, Russia.

17. Baltic Course (2015). Eesti Raudtee financial results for 2014: decline continues. The Baltic Course Magazine, 26.March.2015. Available at URL: http://www.balticcourse.com/eng/transport/?doc=104183 Retrieved: April.2015.

18. Sakiene, Henrika (2011). Regional unemployment regulation during economic slowdown in Lithuania. International Scientific Conference on Economics and Management (Brno, Czech Republic), published in book Journal of Economics and Management, Vol. 16, pp. 309-315.

19. Baltic Sea Ports (2015). Traffic data gathered from webpages of respective sea ports and news articles. Available at URLs: http://www.portgdansk.pl/about-port/cargo-statistics, http://www.haminakotka.fi/fi/haminakotka-satama-oyn-helmikuun-liikennetiedote-2015, http://www.portofhelsinki.fi/helsingin_satama/liikennetilastot, 
http://www.portofklaipeda.lt/news/660/570/Silver-spring-of-2015-in-Klaipeda-Seaport, http://www.rop.lv/en/about-port/statistics.html, http://www.pasp.ru/dannye po gruzooborotu, http://www.portoftallinn.com/key-figures, http://www.portofventspils.lv/en/port-in-general/port-innumbers, Retrieved: 27-30.March. 2015

20. Corbett, J.J., Fischbeck, P.S., \& Pandis, S.N. (1999). Global nitrogen and sulfur inventories for oceangoing ships. Journal of Geophysical Research: Atmospheres, 104:3, pp. 3457-3470.

21. Global Ports (2015). Investor Fact Sheet. September 2014. Available at URL: http://www.globalports.com/globalports/dlibrary/panda/Fact_Sheet_Sep\%202014.pdf Retrieved: April.2015. 